\title{
Wild Boars (Sus scrofa scrofa) Seminiferous Tubules Morphometry
}

\author{
Deiler Sampaio Costa ${ }^{1 *}$ and José Frederico Straggiotti Silva ${ }^{2}$ \\ ${ }^{1}$ Laboratório de Saúde Animal; deiler@uenf.br; ${ }^{2}$ Laboratório de Reprodução Animal; Universidade Estadual do \\ Norte Fluminense; Av. Alberto Lamego, 2000; 28013-600; Campos dos Goytacazes - RJ - Brasil
}

\begin{abstract}
The aim of this data was to analyze morphology and function of the seminiferous tubule in adult wild boars. Testes removed by unilateral castration of five animals were used. The testicular parenchyma was composed by $82.1 \pm 2.2 \%$ of seminiferous tubule and $17.9 \pm 2.2 \%$ of intertubular tissue. The tubular diameter was $249.2 \pm 33.0 \mu \mathrm{m}$ and the seminiferous tubule lenght per gram of testis was $19.3 \pm 4.9 \mathrm{~m}$. The spermatogonial mitoses efficiency coefficient, meiotic index and spermatogenesis efficiency were 10.34, 2.71 and 30.5 respectively. Each Sertoli cell supported about 13 germinatives cells. The hystometric parameters studied were very similar to those related for domestic boars, however, the wild boars intrinsic efficiency of spermatogenesis and Sertoli cells indexes were smaller than in domestic boars.
\end{abstract}

Key words: Seminiferous tubule, wild boar, Sus scrofa scrofa

\section{INTRODUCTION}

The spermatogenesis is an organized and complex process that takes place within the seminiferous tubules in sexually mature animals. This is divided in three distinct phases: proliferative, meiotic and differentiation phase. Although general organization of spermatogenesis is similar in all mammalians, there are particular characteristics among the species as volumetric proportion that is occupied by testicular parenchyma components, number of spermatogonia generations, cellular population in seminiferous tubules, sperm daily production, Sertoli cell rate and general spermatogenesis yield (França and Russell, 1998).

The wild boar (Sus scrofa scrofa) is a non domestic swine that was originally spread in Eurasia and a big part of the African continent. There was also a plentiful population of this species in the continental islands of Europe and The Philippines (Nowak, 1999). Through human action, the wild boar was diffused to other continents due to nutritive qualities and its meat appreciable taste. Its precise entrance place in South America is not well known. However, it is known that this species has adapted well to Argentina's natural conditions, forming a big population. From this initial habitat, wild boars have spread out until the south of Chile, Brazil and also Uruguay (Ciluzzo et al., 2001). This swines commercial production in Brazil was initiated in the 1980's, when farmers in the Rio Grande do Sul state acquired animals from zoo and Argentina to sell in the local market. With the great acceptance meat by the consumers, the production intensified and spread throughout the country (Gimenez, 2001). Thus, during the 1990's, the first farms in the São Paulo state were initiated, with animals

* Author for correspondence 
from the Rio Grande do Sul state. At present, these states are the biggest wild boar meat producers in the country, while Minas Gerais, Paraná, Espírito Santo, Mato Grosso and Mato Grosso do Sul states present a still modest contribution in the consumer market.

The domestic boars have $2 n=38$ chromosomes, independent of its origin and breed, while the European wild boar has $2 \mathrm{n}=36$ chromosomes (Darre et al., 1992). The fact that the European wild boar belongs to the same species that the domestic boar, that these sub-species crossbreeding results in hybrids with normal fertility for the species (Ciluzzo et al., 2001; Gimenez, 2001) and that the hybrid phenotype allows mistakes in the pure animals identification, have taken some misinformed, or unscrupulous farmers to practice this cross-breeding as a way of enhancing their animals zootechnical indexes (Gimenez, 2001). However, when this kind of coupling is performed, even with the intention of taking advantage of the domestic swine better growth conditions, it creates animals with meat presenting peculiar organoleptic characteristics (Matsuoka et al., 1991).

Although the wild boars commercial potential has been largely explored in the last decade, researches involving its reproductive biology are still scarce. However, it is known that the first parturition in wild boars occurs by 13 months, with variation of 2 to 9 sucklings per year (mean 4 pigs) and the parturition interval is roughly 7 months (Gimenez, 2001). In the same study, it was observed that the domestic boars have a greater reproductive efficiency than the wild boars, which easily be explained by short time of artificial selection, due to the recent implantation of these animals farms. In Argentina, it is known that the wild boars reproductive season begins in AprilMay and ends in October (Ciluzzo et al., 2001). In Brazilian farms, no seasonal effect been observed over this species reproduction.

This work aimed to study the wild boars seminiferous tubules morphometric and functional characteristics, since the information about the males reproductive physiology in this species were still scarce.

\section{MATERIAL AND METHODS}

Five adult European wild boars (12.6 \pm 0.9 months old), from a specialized farm "Yacan do Alto Agronegócios Ltda" (confinement system) were used in this work. The animals were weighed, sedated with $1.0 \mathrm{ml} / 20 \mathrm{~kg}$ azaperone and after the perineum and scrotum skin antisepsis, submitted to anesthetic infiltration in the surgical incision line for the unilateral castration accomplishment as a routine technique. Soon after the surgery, the testis was separated from its respective epididymis, weighed and the testicular artery was canulated for perfusion with saline solution $0.9 \%$, with $5,000 \mathrm{UI}$ heparine per liter solution for five minutes at room temperature. Immediately after this testes were again perfused with a glutaraldehyde $4 \%$ fixative solution in phosphate buffer $0.05 \mathrm{M}, \mathrm{pH} 7.2$ for 20 minutes. The testicular parenchyma samples, 1.0 to $3.0 \mathrm{~mm}$ thick, were taken from the organ capitata extremity, the medium third and the caudate extremity. The collection was always made near the tunica albuginea. Such fragments were refixed by immersion in a new glutaraldehyde $4 \%$ solution in phosphate buffer for at least one hour and were later stored at $4^{\circ} \mathrm{C}$ until their histological processing.

The samples were dehydrated in alcohol $(70,80$, 90, 95 and $100 \%$ ) in changes every 30 minutes. After this the fragments were infiltrated with glycol methacrylate solution I (Leica Historesin Embedding Kit - Leica Instruments) for two hours and then they were transferred to the glycol methacrylate solution II, where they stood for 12 . Next, the testicular fragments were included in the same resin with a catalyst addition, as the fabricant's recommendation. The fragments were kept in a bottle containing silica gel until they were completely dry. Four micrometer thickness cuts were performed using glass razor in microtome. The sections were stained with toluidine blue-sodium borate $1 \%$, as routine technique.

The histological sections were photographed in a Nikon E-600 microscope endowed with a digital camera and analyzed with the ImageJ $1.33 \mathrm{~s}$ software (Wayne Rasband - National Institute of Health, USA). The seminiferous tubules mean diameter was obtained from the diameter of 20 transverse sections in each testis measurement, independent the cycle stage. In the same section in which tubular diameter was obtained, the seminiferous epithelium height was also measured, considering the basal membrane until the lumen border. Two notes were obtained from each transverse section, considering as the representative measurement the mean of both. The testicular parenchyma components volumetric rate 
was estimated using a 400 points grid. In each animal, 15 fields were examined randomly. The seminiferous tubules and the intertubular tissue were computed.

The seminiferous tubules cell population was estimated by counting of the spermatogenic lineage different cell types nucleus, as the Sertoli cells nucleolus in the stage 1 of the seminiferous epithelium cycle, characterized according to the tubular morphology system (Berndtson and Desjardins, 1974). Each cell type (Sertoli cells, spermatogonia, spermatocytes and spermatids) was counted in at least 10 tubules transverse sections in stage 1 of the cycle. The counting was corrected for the average nuclear diameter and the thickness of the cut using the Abercrombie (1946) formula, modified by Amann (1962). Because the Sertoli cell presented an irregular nucleus, this amount correction was made from the average nucleolar diameter.

The spermatogenesis intrinsic yield was determined based on the proportions found among the corrected cell numbers. The following proportions were calculated: spermatogonial mitoses efficiency coefficient (proportion between the number of primary spermatocytes in preleptotene/leptotene and the number of spermatogonia A); meiotic index (proportion between the number of rounded spermatids and the number of pachytene primary spermatocytes); general spermatogenesis efficiency (proportion between the rounded spermatids and the number of type A spermatogonia); and the cellular losses occurrence during the meiotic prophase (proportion between the primary spermatocytes number in pre-leptotene/leptotene and the pachytene primary spermatocytes number).

The Sertoli cells support capacity in relation to the different seminiferous epithelium cellular types, was evaluated from the following cellular proportions: spermatogonia A / Sertoli cells; primary spermatocytes (I) in pre-leptoteneleptotene / Sertoli cells; spermatocytes I in pachytene / Sertoli cells; rounded spermatids / Sertoli cells; and the total germinative cells / Sertoli cells. All the proportions were calculated using the cellular counts of the stage 1 of the cycle.

All data were analyzed with the "Excel for Windows" software, and the results obtained were expressed as mean \pm standard deviation according to Sampaio (1998).

\section{RESULTS AND DISCUSSION}

The animals body weight (Table 1) was about $38 \%$ smaller than the value related by Almeida (2002), who also worked with wild boars in confinement systems. Such differences were probably due to the differences in the feeding management between the farms and age in both cases. Wild boars were considerably lighter when compared to swine of specialized breeds in similar ages. However, when there non-specialized breeds were used, as the African pigs, weighing around $34 \mathrm{~kg}$ (Okwun et al., 1996), and the Vietnam pigs with a $42 \mathrm{~kg}$ average (Evans and Ko, 1990), it noticed that the differences were not that divergent. The testis weight in the animals of the present work (Table 1) was about three times smaller than those related by Almeida (2002). Part of this difference seemed to be explained by the difference of body weight among the animal groups. On the other hand, it is common that differences of up to $50 \%$ are observed for the testicular weight in individuals of a same species in similar ages (Berndtson et al., 1987).

The testis percentile occupied by tunica albuginea and mediastinum was about $9.5 \%$ (Table 1). Subtracting this percentile from the testicular weight, approximately $18.5 \mathrm{~g}$ was obtained, which corresponded to the testicular parenchyma weight. The testis weight was directly converted in volume, since the density of this organ was approximately 1.04 (Costa et al., 2004). Thus, the animals testicular parenchyma mean value was considered as $18.4 \pm 3.7 \mathrm{ml}$ (Table 1 ).

The testicular parenchyma components volume density varied a lot among species, but in general, the percentile occupied by seminiferous tubules was around 60 to $90 \%$ (Setchell, 1982) for most of the mammals. The values found in this data $82.1 \pm 2.2 \%$ (Table 1 ) were very similar to those reported by Almeida (2002) and they were similar to reported for domestic boars (Okwun et al., 1996, França and Russell, 1998).

The tubular diameter mean values and the seminiferous epithelium height are show in Table 1. The seminiferous tubules linear retraction factor due to histological processing with plastic resin was estimated in 5\% (Amann, 1981). The tubular diameter value was considered typical for most of the amniotes (180 to $300 \mu \mathrm{m})$ (Roosen-Runge, 1977). The results obtained in this experiment were inserted in this average $(249.2 \pm 33.0 \mu \mathrm{m})$ and 
were very close to those related for sexually mature boars (Godinho and Cardoso, 1979, França, 1991). Usually the tubular diameter is used as a spermatogenic activity indicator when studying the testicular function. The non-seasonal animals average tubular diameter does not suffer significant changes after sexual maturity (França and Russell, 1998). The testis size increase after this period is due to the tubule length increase and not its diameter (Attal and Courot, 1963).

The seminiferous epithelium height found for wild boars in this experiment $(67.5 \mu \mathrm{m})$ was inserted in the interval related for domestic animals, 60 to $100 \mu \mathrm{m}$ (França and Russell, 1998) and was very similar to the reported for boars (Okwun et al., 1996). This did not vary among the seminiferous epithelium cycle at different stages, in spite of the different cellular associations in each one (Wrobel et al., 1995).

The seminiferous tubules total length is a parameter dependent on the testis weight and the seminiferous tubules volume. Thus, animals with bigger testicular weight and volumetric rate of the similar seminiferous tubules have an obvious advantage on those with smaller testicular weight. Hence, the comparisons among animals of different testicular weight makes no sense. Therefore, when converting the seminiferous tubules total length in the seminiferous tubules length per gram of testis, these comparisons become possible. In general, most mammals present about 10 to $20 \mathrm{~m}$ of seminiferous tubules per gram of testis (França and Russell, 1998). Thus, wild boar, with almost 20 meters, is among the species with the largest values for that parameter.

Table 1 - Biometric and Histometric data in wild boar testis

\begin{tabular}{lr}
\multicolumn{1}{c|}{ Parameters } & Mean \pm sd \\
\hline Body weight $(\mathrm{kg})$ & $24.8 \pm 3.6$ \\
Testis weight $(\mathrm{g})$ & $20.2 \pm 3.7$ \\
Albuginea + mediastinum volume density $(\%)$ & $9.4 \pm 2.0$ \\
Testicular parenchyma volume $(\mathrm{ml})$ & $18.4 \pm 3.7$ \\
Testis parenchyma volume density $(\%)$ & $82.1 \pm 2.2$ \\
Seminiferous tubule & $17.9 \pm 2.2$ \\
Intertubular compartment & $249.2 \pm 33.0$ \\
Tubular diameter $(\mu \mathrm{m})$ & $67.5 \pm 2.4$ \\
Seminiferous epithelium height $(\mu \mathrm{m})$ & \\
Tubular seminiferous lenght $(\mathrm{m})$ & $392.9 \pm 81.8$ \\
Per testis & $19.3 \pm 4.9$ \\
Per gram of testis & \\
\hline
\end{tabular}

The wild boars seminiferous tubules cellular population is presented in Table 2. The cellular amounts were corrected because there was a great variability of results when gross numbers were used for comparisons among different species and even among individuals of a same species (Cardoso, 1981). Such variation was mainly due to differences in the methodology used which could make unfeasible comparisons among different authors. However, even corrected, the results obtained should be considered only as a tendency indicative (França, 1991), because other factors such as different samplings, age, breed and genetic selection, could also interfere in the counting final result. Although the spermatogonia A number was similar to the reported for Piaus boars (França,
1991), the other germinate cells and Sertoli cells population were invariably smaller than the values found in most of the domestic boars breed (Godinho and Cardoso, 1979, Wettermann and Desjardins, 1979, França, 1991).

The most used form to estimate the spermatogenic process efficiency in mammals is from numeric proportions among the cellular types for transverse section in the stage 1 of the cycle. Thus, it is possible to make comparative studies among individuals of a same species and among different species, besides allowing locating the phases in which cellular losses happen and to quantify them in percentile terms (Russell et al., 1990). 
Table 2 - Tubular cells population at stage 1 of the epithelium seminiferous cycle in wild boars ${ }^{1}$

\begin{tabular}{c|c|c|c|c|c}
\hline Animal & SC & A & PL/L & P & RS \\
\hline 1 & 6.05 & 1.89 & 18.66 & 18.78 & 54.61 \\
2 & 7.84 & 1.96 & 18.24 & 23.65 & 49.23 \\
3 & 8.10 & 1.65 & 15.44 & 17.49 & 57.91 \\
4 & 7.40 & 1.36 & 19.87 & 17.56 & 51.72 \\
5 & 6.92 & 1.79 & 17.26 & 19.86 & 50.34 \\
\hline mean \pm sd & $7.26 \pm 0.81$ & $1.73 \pm 0.24$ & $17.89 \pm 1.66$ & $19.47 \pm 2.53$ & $52.76 \pm 3.51$ \\
\hline
\end{tabular}

SC - Sertoli cells; A - type A spermatogonia; PL/L - preleptotene-leptotene primary spermatocytes, $\mathrm{P}$ - pachytene primary spermatocytes, RS - round spermatids.

${ }^{1}$ Corrected cell numbers according Amann (1962)

Table 3 - Intrinsic efficiency of spermatogenesis and Sertoli cell index in wild boars

\begin{tabular}{lr}
\multicolumn{1}{c}{ Parameters } & index \\
\hline Intrinsic efficiency of spermatogenesis & \\
Spermatogonial mitoses efficiency coefficient & 10.34 \\
Meiotic index & 2.71 \\
Spermatogenesis efficiency & 30.50 \\
Cellular losses occurrence during the meiotic prophase & 1.09 \\
Sertoli cells index & \\
Sertoli cells : A spermatogonia & 0.24 \\
Sertoli cells : Preleptotene-leptotene primary spermatocytes & 2.46 \\
Sertoli cells : Pachytene primary spermatocytes & 2.68 \\
Sertoli cells : Round spermatids & 7.27 \\
Sertoli cells : Total germinative cells & 12.65 \\
\hline
\end{tabular}

With this aim, four rates are commonly used: the spermatogonial mitoses efficiency coefficient, the meiotic index, the spermatogenesis efficiency and the cellular losses occurrence during the meiotic prophase. The results obtained in the animals of the present research are presented in Table 3.

The spermatogonial mitoses efficiency coefficient indicated that in stage 1 , each spermatogonia $A_{1}$ was responsible for the formation of 10.34 spermatocytes I in pre-leptotene/leptotene and was directly associated to the studied species spermatogonia generations number. Analyzing the data reviewed by França and Russell (1998), it was noticed that most of the animals investigated possessed six spermatogonia differentiated generations $\left(\mathrm{A}_{1-4}\right.$, In and $\mathrm{B}$ or $\left.\mathrm{A}_{1-3}, \operatorname{In}, \mathrm{B}_{1-2}\right)$, in this case, theoretically one spermatogonia $A_{1}$ would form 64 spermatocytes $I$ in preleptotene/leptotene, if there were not cellular losses during that phase. Species like equine and rabbits have five spermatogonia differentiated generations $\left(\mathrm{A}_{1-3}, \quad \mathrm{~B}_{1-2}\right.$ and $\mathrm{A}_{1-2}, \mathrm{In}_{1-2}, \mathrm{~B}$, respectively). Therefore, 32 spermatocytes $\mathrm{I}$ in pre-leptotene/leptotene would be formed from one spermatogonia $\mathrm{A}_{1}$.
Considering that the spermatocytes I number theoretically expected in pre-leptotene/leptotene in wild boars was 64 cells, an approximate loss of $84 \%$ during the spermatogonial divisions of that species was considered. About 60 to $80 \%$ of cellular losses, in relation to the spermatocytes I number theoretically expected in preleptotene/leptotene, have been found in animals of most the articles reviewed by França and Russell (1998).

Starting from the meiotic index it could be verified that one spermatocyte $I$ in pachytene had generated 2.71 rounded spermatids, being equal to a loss of $32.5 \%$ when it was compared to the expected theoretical proportion (1:4) if the spermatogenesis efficiency was $100 \%$. A similar result was found in adult boars (França, 1991), as well as in several species of domestic animals (França and Russell, 1998). The spermatocyte I population during the meiotic prophase in the animals in this experiment remained constant as related for the great majority of the mammals (Berndtson and Desjardins, 1974, Godinho and Cardoso, 1979, Billaspuri and Guraya, 1986).

The wild boars spermatogenesis efficiency was roughly $12 \%$, i.e., one spermatogonia A produced 
only 30.5 rounded spermatids. Considering that this process yield was $100 \%, 256$ rounded spermatids would be produced. According to França (1991), the domestic boars presented a larger intrinsic efficiency of spermatogenesis (26.6\%, than the wild boars, $12 \%)$. Several authors have reported degenerations and cellular losses during the spermatogonial proliferation phase and the spermatogenic process meiotic divisions in animals without any reproductive alteration (Berndtson and Desjardins, 1974, Billaspuri and Guraya, 1984, Roosen-Runge, 1973). Apoptosis plays a fundamental role during the normal development and in multi-cellular organisms homeostasis (Jacobson et al., 1997). In the seminiferous epithelium, apoptosis usually happens spontaneously or in response to several factors such as chemotherapy, high temperature, hormonal disturbances and growth factors decrease (Blanco-Rodríguez and Martínez-Garcia, 1998).

The equilibrium between proliferation and apoptosis plays a very important role in the regulation of the spermatogenic cells number in the seminiferous epithelium. Particularly in the spermatogonial phase, the apoptosis regulation homeostatic mechanism is considered densitydependent, limiting the amount of germinate cells which enter in the meiotic phase to a number that can be supported by the Sertoli cells available (Huckins, 1978, Sharpe, 1994). The Sertoli cells indexes are indicative parameters of the capacity those cells have to support germinate cells in the seminiferous epithelium, i.e., they reflect the Sertoli cells functional efficiency in a species (França and Russell, 1998). Therefore, species in which Sertoli cells support a larger amount of germinate cells tend to have a larger daily spermatic production, when compared to those that have smaller values for that parameter.

In this work 7.27 rounded spermatids for each Sertoli cell were found (Table 3). This value was about $40 \%$ smaller than the found for Piaus boars (12.4 - França, 1991). This difference was sustained for the other indexes, except in the case of the spermatogonia A number that was supported by Sertoli cells, which was similar to the value found by França (1991). The result seemed to be a reflex of the selection process to which the domestic boars were submitted, that probably culminated in more efficient Sertoli cells.

It was concluded that the histometric parameters studied in this work were very similar to the values reported for domestic boars, however, the intrinsic efficiency of spermatogenesis and the wild boars Sertoli cells indexes were relatively low when compared to those animals and to the other mammals already investigated.

\section{RESUMO}

Objetivou-se com esta pesquisa estudar as características morfométricas e funcionais dos túbulos seminíferos de javalis adultos. Utilizaramse testículos de cinco animais submetidos a orquiectomia unilateral. O parênquima testicular foi composto por $82,1 \pm 2,2 \%$ de túbulos seminíferos e $17,9 \pm 2,2 \%$ de tecido intertubular. O diâmetro tubular foi de $249,2 \pm 33,0 \mu \mathrm{m}$ e o comprimento dos túbulos seminíferos por grama de testículo foi de 19,3 $\pm 4,9 \mathrm{~m}$. O coeficiente de eficiência das mitoses espermatogônias, o rendimento meiótico e o rendimento geral da espermatogênese foram, respectivamente, 10,34, 2,71 e 30,50. Cada célula de Sértoli suportou cerca de 13 células germinativas. Conclui-se que os parâmetros histométricos estudados nesta pesquisa foram muito semelhantes aos valores relatados para suínos domésticos, entretanto, o rendimento intrínseco da espermatogênese e os índices de células de Sértoli de javalis foram relativamente baixos quando comparados com aqueles animais.

\section{REFERENCES}

Abercrombie, M. (1946), Estimation of nuclear populations from microtome sections. Anat. Rec., 94, 238-248.

Almeida, F. F. L. (2002), Estrutura e função testiculares em javalis (Sus scrofa scrofa) sexualmente maduros. MS Thesis, Universidade Federal de Minas Gerais, Belo Horizonte, Brazil.

Amann, R. P. (1962), Reproductive capacity of dairy bulls. IV. Spermatogenesis and testicular germ cell degeneration. Am. J. Anat., 110, 69-78.

Amann, R. P. (1981), A critical review of methods for evaluation of spermatogenesis from seminal characteristics. J. Androl., 2, 37-58.

Attal, J. and Courot, M. (1963), Développement testiculaire et établissement de la spermatogénèse chez le taureau. Ann Biol. Anim. Bioch. Biophys., 3, 219-241.

Berndtson, W. E. and Desjardins, C. (1974), The cycle of the seminiferous epithelium and spermatogenesis in the bovine testis. Am. J. Anat., 140, 167-180. 
Berndtson, W. E.; Igboeli, G. and Pickett, B. W. (1987), Relationship of absolute number of Sertoli cells to testicular size and spermatogenesis in young beef bulls. J. Anim. Sci., 64, 241-246.

Bilaspuri, G. S. and Guraya, S. S. (1986), The seminiferous epithelial cycle and spermatogenesis in rams (Ovis aries). Theriogenol., 25, 485-505.

Bilaspuri, G. S. and Guraya, S. S. (1984), The seminiferous epithelial cycle and spermatogenesis in goats (Capra hircus). J. Agric. Sci., 103, 359-368.

Blanco-Rodriguez, J. and Martínez-Garcia, C. (1998). Apoptosis pattern elicited by several apoptogenic agents on the seminiferous epithelum of the adult rat testis. J. Androl., 19, 487-497.

Cardoso, F. M. (1981), Morfologia, cinética e quantificação da espermatogênese em zebus (Bos indicus). DS Thesis, Universidade Federal de Minas Gerais,Belo Horizonte, Brazil.

Ciluzzo, J. N.; Vieites, C. M.; Basso, C. P. et al. (2001), Jabalies cruza en Argentina: crescimiento, conversion alimentícia y reses. In. Vet., 3, 49-53.

Costa, D. S.; Henry, M. and Paula, T. A. R. (2004), Espermatogênese de Catetos (Tayassu tajacu). Arq. Bras. Med. Vet. Zootec., 56, 46-51.

Darre, R. ; Berlandh, M.; Goustat, A. (1992), Statut chromosomique des populations de sangliers souvages et d'élevages en France. Rev. Med. Vet., 143, 225-232.

Evans, L. E. and Ko, J. C. H. (1990), Electroejaculation and artificial insemination in vietnamese potbellied miniature pigs. J. Am. Vet. Med. Assoc., 197, 1366-1367.

França, L. R. (1991), Análise morfofuncional da espermatogênese de suínos adultos da raça piau. $\mathrm{PhD}$ Thesis, Universidade Federal de Minas Gerais, Belo Horizonte, Brazil.

França, L. R. and Russell, L. D. (1998), The testis of domestic animals. In: Regadera, J. and MartinezGarcia, F. (Eds.). Male reproduction. A multidisciplinary overview. Madrid: Churchill Livingstone. pp.197-219.

Gimenez, D. L. (2001), Análise cromossômica do javali europeu Sua scrofa $e$ de hibridações com o suíno doméstico Sus scrofa domesticus comparando as características qualitativas da carcaça e da carne. MS Thesis, Universidade Estadual Paulista Julio de Mesquita Filho, Botucatu, Brazil.

Godinho, H. P. and Cardoso, F. M. (1979), Desenvolvimento sexual de porcos Yorkshire. II. Estabelecimento e evolução da espermatogênese. Arq. Esc. Vet. UFMG, 31, 351-361
Huckins, C. (1978), The morphology and kinetics of spermatogonial degeneration in normal adult rats: an analysis using a simplified classification of the germinal epithelium. Anat. Rec., 190, 905-26.

Jacobson, M. D.; Weil, M. and Raff, M. C. (1997), Programmed cell death in animal development. Cell., 88, 347-354.

Matsuoka, A.; Yamano, J.; Furokawa, N. et al. (1991), Studies on meat quality of pigs crossbed with wild boars. Jap. J. S. Sci., 28, 203-212.

Nowak, R. M. (1999), Walker's mammals of the world. 6. ed. London: Johns Hopkins University Press. v. 2. pp. 1053-1062.

Okwun, O. E.; Igboeli, G.; Ford, J. J. et al. (1996), Number and function of sertoli cells, number and yield of spermatogonia, and daily sperm production in three breeds of boar. J. Reprod. Fertil., 107, 137-149.

Roosen-Runge, E. C. (1973), Germinal-cell loss in normal metazoan spermatogenesis. J. Reprod. Fertil., 35, 339-348.

Roosen-Runge, E. C. (1977), The process of spermatogenesis in animals. Cambridge: University Press.

Russell, L. D.; Ettlin, R. A.; Sinha-Hikim, A. P. et al. (1990) Histological and histopathological evaluation of the testis. Clearwater, Florida: Cache River Press.

Sampaio, I. B. M. (1998), Estatística aplicada à experimentação animal. Belo Horizonte: FEPMVZ, UFMG.

Setchell, B. P. (1982), Spermatogenesis and spermatozoa. In: Austin, C. R. and Short, R. V. (Eds.). Reproduction in mammalian. London: Elek. pp. 63-101.

Sharpe, R. M. (1994), Regulation of spermatogenesis. In: Knobil, E. and Neil, J. D. (Eds.). The phisiology of reproduction. $2^{\text {nd }}$ ed. New York: Raven Press. pp.1363-1434.

Wettermann, R. P. and Desjardins, C. (1979), Testicular function in boars exposed to elevated ambient temperature. Biol. Reprod., 20, 235-241.

Wrobel, K. H.; Reichold, J. and Schimmel, M. (1995), Quantitative morphology of the ovine seminiferous epithelium. Anat. Anz., 177, 19-32. 